\section{Marina Dedić}

Centar za odgoj i obrazovanje Slava Raškaj, Split

Ana Leko Krhen

Svenčiliste u Zagrebu, Edukacijsko-rehabilitacijski

fakultet, Odsjek ra logopediju

\section{Utjecaj jezičnih sposobnosti na mucanje}

\author{
The influence of language abilities on \\ stuttering
}

\begin{abstract}
SAŽETAK
Cilj je rada analizirati i prikazati jednu generaciju obitelji genetski opterećenu mucanjem. Obitelj je analizirana s obzirom na njihovo obiteljsko stablo, jakost mucanja ispitanika i njihove osjećaje vezane uz mucanje tijekom razgovora, vrstu i količinu netečnosti u govoru te jezične sposobnosti i utjecaj jezične obrade na mucanje. Sudionici istraživanja su četiri brata i svi su članovi jedne generacije obitelji P., dobi od 7 do 23 godine. U istraživanju su primijenjeni mjerni instrumenti: Peabody slikovni test rječnika-IIIhrvatsko izdanje, Stuterring Severity Instrument te materijal oblikovan u cilju istraživanja, a ispituje utjecaj leksičkog priziva i sintaktičke složenosti na mucanje.

Rezultati pokazuju pojavnost mucanja u obitelji i s majčine i s očeve strane, ali samo kod muških članova. Jakost mucanja razlikuje se od ispitanika do ispitanika, a kreće se od tečnog govora do teškog mucanja. Potvrđuje se postojanje nižih jezičnih sposobnosti kod polovice ispitanika. S obzirom na vrstu i količinu netečnosti najviše je zastoja. Ispitanicima je najteže voditi razgovor s autoritetima. Sintaktička složenost nije se pokazala utjecajnom na govornu tečnost, a leksički priziv utječe na govor samo kod ispitanika koji pokazuje ispodprosječne jezične sposobnosti. Navedeno potvrđuje da je mucanje heterogen poremećaj, na koji utječe više čimbenika - genetika, jezik, zrelost, okolina i slično.
\end{abstract}

\begin{abstract}
The aim of the paper is to analyze and present a generation of a family genetically loaded with stuttering. The family was analyzed with regards to their family tree, the strength of stuttering of participants and their feelings related to stuttering during conversation, the type and amount of dysfluency, the language ability and the impact of language processing on stuttering. Research participants were four brothers who are all members of one generation of the P. family. Their age range varies from 7 to 23 years. Measuring instruments used in the research are: Peabody Picture Vocabulary Test-III-Croatian Edition, Stuttering Severity Instrument and material designed for the research that measures the influence of lexical retrieval and syntactic complexity on stuttering.

The results show the appearance of stuttering in the family, both on mother and father's side, but only in male members. Stuttering severity varies from participant to participant, ranging from fluent speech to severe stuttering. The existence of lower language abilities in half of the respondents is confirmed. Due to the type and quantity of dysfluency, the most frequent are breaks. Participants find it hardest to talk to the authorities. Syntactic complexity does not influence on fluency and lexical retrieval affects speech only in participants who show under-average language abilities. The above confirms that stuttering is a heterogeneous disorder influenced by several factors, such as genetics, language, maturity, environment, and the like.
\end{abstract}

\author{
Ključne riječi: \\ mucanje \\ genetika - \\ jezične \\ sposobnosti - \\ PPVT - SSI- \\ 4
}

Keywords: stuttering genetics language abilities PPVT -

SSI-4 


\section{UVOD}

Mucanje najčešće počinje $u$ ranom djetinjstvu jer su u tom razdoblju djeca pod utjecajem uže okoline, govorni aparat se anatomski razvija, time i govor i jezik. U ovim razvojnim procesima uloga roditelja, ali i ranjivosti u sustavu govorne tečnosti može biti presudna u pojavi mucanja (Yairi i Seery, 2015). Točni uzroci mucanja još nisu poznati, no postoje razne teorije koje se time bave. Starkweather i Gottwald (1990) kao uzrok mucanja izdvajaju obiteljsko okruženje. Poznat je i njihov Model zahtjeva i sposobnosti, koji navodi neusklađenost u zahtjevima okoline s djetetovim jezičnim i kognitivnim sposobnostima (Starkweather i Gottwald, 1990). Prisutnost karakterističnih jezičnih obilježja kod osoba koje mucaju ukazuju i na to da je uzrok mucanja možebitno u nekoj slabosti u pronalaženju ili sastavljanju rečeničnih elemenata. No, nije jasno je li mucanje posljedica narušene jezične obrade ili općih ograničenja kapaciteta, od kojih je jezična obrada samo jedan dio (Bernstein Ratner, 2007). Bez obzira koji je uzrok mucanja, gotovo je sigurno to da je ono velikim dijelom genetski prenosivo.

\section{Genetika i obiteljska opterećenost}

Kliničari koji rade s osobama koje mucaju uočili su da je mucanje često prisutno u obitelji. Pregledom istraživanja uočeno je da 30-60 \% osoba koje mucaju imaju obiteljsku povijest mucanja, dok manje od $10 \%$ osoba koje ne mucaju imaju zabilježeno mucanje u obitelji (Yairy, Ambrose i Cox, 1996). O velikom utjecaju genetske komponente na pojavnost mucanja, svjedoče nam istraživanja o većo usklađenosti mucanja kod jednojajčanih nego kod dvojajčanih blizanaca (Ooki, 2005; van Beijsterveldt, Felsenfeld i Boomsma, 2010). Primjer toga je nizozemsko istraživanje, u kojem se navodi da je usklađenost mucanja 57 $\%$ kod jednojajčanih te $31 \%$ u dvojajčanih blizanaca (van Beijsterveldt, Felsenfeld i Boomsma, 2010). Poznato je da jednojajčani blizanci dijele $100 \%$ gena, a dvojajčani dijele 50 $\%$ gena. Međutim, da je mucanje samo genetski nasljedno, onda bi u svakom slučaju mucanja jednog para jednojajčanih blizanaca mucao i drugi par. Činjenica da nije tako, govori u prilog utjecaju okolinskih čimbenika na pojavnost mucanja. Stoga se zaključuje da je moguće da se predispozicija za mucanje nasljeđuje, ali se mucanje javlja samo pod određenim okolnostima. Genotipizacijska istraživanja pronašla su kromosome koji se najviše mogu povezati s mucanjem, ali nisu izdvojili izolirane gene uzročnike budući da se vjerojatno radi o kombinaciji više gena. Zato je teško reći što se točno tim genima prenosi i utječe li na motorički, jezični ili neki drugi čimbenik u razvoju govora. Unatoč nepoznanicama, ove spoznaje o genetici i mucanju korisne su u kliničkom radu logopeda s osobama koje mucaju. Ako je u obitelji osobe koja muca prisutna povijest kroničnog mucanja, to implicira da će i ta osoba imati veći rizik za kronično mucanje nego za spontani oporavak od mucanja (Yairy i Seery, 2015). Nadalje, Barnes MacFarlane i suradnici (1991) istraživali su nekoliko generacija iste obitelji, navode da muške osobe češće mucaju od ženskih i da se mucanje češće prenosi s oca/majke na sina, nego s oca/majke na kćer. No, ako oba roditelja mucaju - ne znači da će cijelo potomstvo mucati, to se osobito odnosi na žene.
Kod obiteljske opterećenosti mucanjem, ne mogu se zanemariti i njegove socijalne interpretacije i omjer spolova. Vezano uz socijalne interpretacije, Gray (1940) smatra da na pojavu mucanja utječu stavovi obitelji. Istražujući jednu obitelj, autorica je otkrila da je mucanje češće u dijelu obitelji koja je anksiozno iščekivala njegove znakove na svojoj djeci, u odnosu na drugi dio obitelji koji ne živi blizu i nema takva očekivanja i stavove.

Omjer dječaka i djevojčica u dobi od 2 do 10 godina koji mucaju je nejednak, iznosi 3:1 (muško:žensko) (Bloodstein i Bernstein Ratner, 2008). Ovaj omjer mijenja se s dobi. U kasnom djetinjstvu se povećava (4:1 u dobi od 11 do 20 godina), a u odrasloj dobi se smanjuje (2:1 u dobi od 21 do 49 godina; 1,4:1 u dobi 50+ godina) (Craig i Tran, 2005). Većina autora smatra kako je nejednak omjer dokaz spolno ograničene genetske predispozicije za mucanje te da se dječake nepovoljno uspoređuje s djevojčicama u fizičkom, socijalnom i jezičnom razvoju. Navedeno im stvara nesigurnosti i frustracije (pogotovo u jezičnim situacijama), to vodi do oklijevanja u govoru (Schuell, 1946).

\section{Povezanost jezika i mucanja}

Određene suptilne razlike u jezičnim sposobnostima djece koja mucaju i ne mucaju, potaknule su ideju o povezanosti mucanja i jezika. Uočeno je da, u razdoblju nakon početka mucanja, djeca koja mucaju često kasne u jezičnom razvoju (Bloodstein i Bernstein Ratner, 2008). Počeci mucanja poklapaju se s razvojnom fazom ubrzanog rasta ekspresivnih i receptivnih jezičnih sposobnosti. Prema metaanalizi 22 istraživanja (Ntourou, Conture i Lipsey, 2011), utvrđeno je da djeca koja mucaju pokazuju značajno slabiju izvedbu na mjerama općih jezičnih sposobnosti, rječnika (receptivnog $\mathrm{i}$ ekspresivnog) te prosječne duljine iskaza. Rezultati pokazuju da osobe koje mucaju imaju doista nešto lošije jezične sposobnosti od osoba koje ne mucaju, čak i ako su unutar normalnih granica. Nadalje, najčešce teškoće koje su u komorbiditetu s mucanjem, odnose se na fonološke, artikulacijske i jezične teškoće (Yairy i Seery, 2015).

Spomenuti Model zahtjeva i sposobnosti (Starkweather i Gottwald, 1990) navodi tri činjenice vezane uz jezik i mucanje: 1. mucanje se najčešće javlja na jezično zahtjevnijim mjestima, kao što su duge riječi te duge i složene rečenice, 2. djeca koja mucaju kasne u jezičnom razvoju, 3. ponekad jezično naprednija djeca počnu mucati zbog naglog napretka u jezičnom razvoju. Kod obje skupine djece velika je opterećenost njihovih kapaciteta. S obzirom na to da u određenom razdoblju razvoja (oko treće godine) dolazi do naglog porasta rječnika i dijete počinje govoriti složene rečenice, dulje i fonološki složenije riječi, a to se događa vrlo brzo i u kratkom razdoblju, može se dogoditi da dijete nije spremno. Zbog takve nezrelosti u središnjem živčanom sustavu može doći do pojave netečnosti u govoru (Galić- Jušić, 2001). Činjenica da djeca s kroničnim mucanjem često pokazuju sporiji jezični razvoj nego djeca koja su se spontano od njega oporavila, zahtijeva da se uzme u obzir ideja o povezanosti jednog i drugog, jezika i mucanja (Bloodstein i Bernstein Ratner, 2008). Choi i sur. (2018) otkrili su da djeca koja ne mucaju, a imaju pozitivnu obiteljsku povijest mucanja, pokazuju niže jezične sposobnosti od onih kojima je obiteljska povijest mucanja 
negativna. Kod djece koja mucaju nije zabilježena takva povezanost. Njihova otkrića pokazuju da jezična ranjivost djece može biti povezana s obiteljskom i/ili genetskom predispozicijom za mucanje.

Neki autori smatraju da je uzrok mucanja u teškoćama u leksičkom nalaženju riječi. Pellowski i Conture (2005) navode da je kod djece koja mucaju mentalni leksikon organiziran drukčije ili manje uspješno, što ukazuje na njihovo sporije i neučinkovitije enkodiranje leksičkih informacija. To vodi do veće šanse za pogrešne odabire riječi u planiranju jezično-govornog iskaza. Ako dijete uoči pogrešan odabir može ga pokušati ispraviti, što može dovesti do mucajućeg trenutka. Porastom rječnika rastu i jezične sposobnosti, no veći rječnik znači i teže i dulje traženje odgovarajuće riječi. U skladu s time, Dunn i Dunn (1997) otkrili su da djeca koja mucaju pokazuju niže rezultate na mjeri receptivnog rječnika, koja je dobivena Peabody Picture Vocabulary Testom (PPVT). Pellowski (2011) navodi da odrasli koji mucaju imaju uredno razvijen rječnik. Perkins, Kent i Curlee (1991) zaključuju da razlike između leksičkih i sintaktičkih sposobnosti mogu ometati tečnost govora. Njihov model naglašava da je jezična proizvodnja izbačena iz ravnoteže u slučaju kada je jedna jezična komponenta ispod razine ostalih.

Silverman i Bernstein Ratner (1997) smatraju da je utjecaj jezičnih čimbenika na mucanje jači u dječjoj dobi, kad dolazi do njegove pojave, jer jezične sposobnosti $s$ vremenom ojačaju. Prema njihovu istraživanju, sintaktička složenost rečenica nema utjecaja na frekvenciju mucajućih netečnosti kod adolescenata koji mucaju. Isto tako, Usler i suradnici (2017) navode da se sintaktička složenost i duljina rečenice nisu pokazale utjecajnima na govornu motoričku stabilnost osoba koje mucaju, odnosno da povećanje jezičnih zahtjeva ne uzrokuje neuspješnu artikulacijsku koordinaciju. S druge strane, Kleinow i Smith (2000) pronalaze da povećanje sintaktičke složenosti iskaza destabilizira govor osoba koje mucaju, smatraju kako jezična slabost pridonosi tome.

S obzirom na velik broj dokaza koji podupiru postojanje genetske osnove za mucanje (Yairi i Seery, 2015), cilj je rada prikazati obiteljsko stablo obitelji genetski opterećene mucanjem. Nadalje, cilj je i odrediti stupanj jakosti mucanja ispitanika i utvrditi njihove osjećaje povezane s mucanjem za vrijeme razgovora. Također, u skladu sa zabilježenim sporijim jezičnim razvojem osoba koje mucaju (Bloodstein i Bernstein Ratner, 2008), cilj je i dobiti uvid u razinu jezičnih sposobnosti članova spomenute obitelji te ispitati utječu li zahtjevi jezične obrade na mucanje. Preciznije, cilj je utvrditi utjecaj sintaktički složenih iskaza te leksičkog priziva na pojavu mucajućih netečnosti.

\section{METODE}

\section{Uzorak ispitanika}

Sudionici istraživanja su četiri brata, članovi obitelji P. Raspon njihove dobi kreće se od 7 do 23 godine. Prikupljeni su anamnestički podaci o svakom od ispitanika i o cijeloj obitelji. Podatke je dala majka radi općih informacija o jezično-govornom razvoju ispitanika i izrade obiteljskog stabla. Pri tome je korišten upitnik koji je majka popunila za sva četiri ispitanika. Uzorak ispitanika izabran je na osnovi prosudbe ispitivača. Punoljetni ispitanici dali su svoju suglasnost za sudjelovanje u istraživanju, a za maloljetne ispitanike to je odobrila majka. Također, obitelj je dala svoj pristanak za objavu obiteljskog stabla s njihovim imenima.

Prvi ispitanik je 23-godišnji student koji ima dijagnozu mucanja. Radio je dvije godine u korisničkoj službi jedne telekomunikacijske tvrtke. Mucanje se pojavilo oko pete godine u obliku ponavljanja početnih glasova i slogova uz povremene zastoje. Ispitanik je godinama pohađao logopedsku terapiju i ValMod terapiju. Nema zabilježenih drugih teškoća iz govorno-jezičnog područja.

Drugi ispitanik je 20-godišnji student koji također ima dijagnosticirano mucanje. Kod njega se mucanje javilo malo kasnije, oko osme godine. Počelo je ponavljanjem početnih glasova i slogova uz zastoje i periodično pogoršavanje mucanja. Kratko je pohađao logopedsku terapiju i ValMod terapiju. Nema zabilježenih drugih teškoća iz jezičnogovornog područja.

Treći ispitanik je 16-godišnji učenik srednje strukovne škole. Iako nema službenu dijagnozu i nikad nije pohađao terapiju, i on također muca. Prema anamnestičkim podacima, mucanje je počelo oko osme godine.

Četvrti ispitanik je sedmogodišnjak, predškolske dobi. Trenutno, povremeno pohađa logopedsku terapiju zbog kašnjenja u jezično-govornom razvoju. Počeo je govoriti oko treće godine. Narušen je izgovor sljedećih glasova: L, R, C, $\check{C}, \check{S}, \check{Z}, \mathrm{DZ}$. Mucanja kod ovog ispitanika nema.

\section{Mjerni instrumenti i postupak}

Mjerni instrumenti korišteni u istraživanju su: Peabody slikovni test rječnika-III-hrvatsko izdanje (PPVT-III-HR; Dunn, Dunn i Kovačević i sur., 2009), Stuterring Severity Instrument (SSI-4; Riley, 2009) te materijal oblikovan za istraživanje po uzoru na autore Abel i suradnici (2014), MacPherson i Smith (2013) i Wells (1979). Prvi dio čini 30 rečenica različite sintaktičke složenosti, podijeljenih $u$ tri skupine - po 10 rečenica. U prvoj skupini su jednostavne deklarativne rečenice prosječne duljine od 9,8 slogova. U drugoj skupini su složene rečenice prosječne duljine 21,1 slog. Treća skupina su rečenice koje imaju samo glavnu rečenicu i kojima ispitanik treba dodati zavisnu rečenicu. Potonje je ometajući čimbenik ispitanicima jer zahtijeva dodatnu jezičnu obradu. Zadatak ispitanika je pročitati prve dvije skupine rečenica te pročitati i usmeno dopuniti posljednju skupinu rečenica. Drugi dio čini materijal za ispitivanje leksičkog priziva i čini ga 10 jednostavnih deklarativnih rečenica kojima nedostaje zadnja riječ. Zadatak ispitanika je usmeno dopuniti rečenice imenicama. Ispitanici su podvrgnuti ispitivanju individualno, a snimani su videokamerom. Jezično-govorni iskazi ispitanika su transkribirani i obrađeni. U obradi podataka primijenjene su mjere deskriptivne statistike.

\section{REZULTATI I RASPRAVA}

Prema prikupljenim anamnestičkim podacima izrađeno je obiteljsko stablo ispitane obitelji (Slika 1). Uočljivo je da pet osoba muca i da su svi muškog spola. Nadalje, tri od četiri člana iste generacije mucaju. Ta generacija ujedno 
predstavlja i ispitanike ovog istraživanja. Pojavnost mucanja vidljiva je i s majčine (ujak) i s očeve strane obitelji (otac). Ovaj rezultat potvrđuje dosadašnje tvrdnje da je mucanje češće kod osoba muškog spola te da se ono često prenosi s oca na sina (Barnes MacFarlane i sur., 1991).

Kod najmlađeg ispitanika nema mucanja, a ostali se kreću u različitim rasponima. Kod prvog ispitanika prisutno je vrlo blago mucanje, što nije neobično s obzirom na to da je dugo razdoblje pohađao logopedsku terapiju. Nadalje, važan čimbenik je i dob koja utječe na zrelost, time i na stav o mucanju, kontrolu govora i manju anksioznost vezanu uz mucanje (Croker i Major, 1989). Kod drugog ispitanika prisutno je umjereno mucanje, a kod trećeg teško mucanje, što se podudara s duljinom logopedske terapije

$\mathrm{Za}$ utvrđivanje stupnja jakosti mucanja ispitanika primijenjen je SSI-4. Rezultati pokazuju da $75 \%$ ispitanika (3 od 4) muca (Tablica 1). Kod najmladeg ispitanika nema mucanja, a ostali se kreću u različitim rasponima. Kod prvog ispitanika prisutno je vrlo blago mucanje, što nije neobično s obzirom na to da je dugo razdoblje pohađao logopedsku terapiju. Nadalje, važan čimbenik je i dob koja utječe na zrelost, time i na stav o mucanju, kontrolu govora i manju anksioznost vezanu uz mucanje (Croker i Major, 1989). Kod drugog ispitanika prisutno je umjereno mucanje, a kod trećeg teško mucanje, što se podudara s duljinom logopedske terapije. Tablica 2 prikazuje rezultate PPVTtesta - odnosno receptivni rječnik ispitanika. Dobiveni rezultati u prva dva (najstarija) ispitanika potvrda su istraživanju koje je proveo Pellowski (2011), a odnose se na to da odrasle osobe koje mucaju imaju uredno razvijen rječnik. Dva mlađa ispitanika pokazuju umjereno nizak rezultat. Važno je istaknuti rezultat trećeg ispitanika koji je u skladu s istraživanjem Blooda i suradnika (Blood i sur., 2003), koji navode da $26 \%$ osoba koje mucaju imaju uz to i jezične teškoće. Najmlađi ispitanik ne muca, ali pokazuje ispodprosječne jezične sposobnosti, što može biti u vezi s genetskom predispozicijom za mucanje i/ili nekim jezičnim slabostima. Usporede li se stupanj jakosti mucanja s rezultatima receptivnog rječnika, primjećuje se određeni trend. Štoviše, uzevši u obzir samo rezultate ispitanika koji mucaju, jasno je da veći stupanj jakosti mucanja znači i niži receptivni rječnik. Rezultat četvrtog ispitanika također je u skladu s njegovim zakasnjelim jezično-govornim razvojem.

Tablica 1. Stupanj jakosti mucanja ispitanika

\begin{tabular}{|l|c|c|c|c|}
\hline & $\begin{array}{c}\text { Prvi } \\
\text { ispitanik }\end{array}$ & $\begin{array}{c}\text { Drugi } \\
\text { ispitanik }\end{array}$ & $\begin{array}{c}\text { Treći } \\
\text { ispitanik }\end{array}$ & $\begin{array}{c}\text { Četvrti } \\
\text { ispitanik }\end{array}$ \\
\hline $\begin{array}{l}\text { Ukupan } \\
\text { rezultat }\end{array}$ & 12 & 27 & 30 & 0 \\
\hline $\begin{array}{l}\text { Postotni } \\
\text { rang }\end{array}$ & $1-4$ & $41-60$ & $78-88$ & 0 \\
\hline $\begin{array}{l}\text { Stupanj } \\
\text { jakosti } \\
\text { mucanja }\end{array}$ & $\begin{array}{c}\text { Vrlo } \\
\text { blago } \\
\text { mucanje }\end{array}$ & $\begin{array}{c}\text { Umjereno } \\
\text { mucanje }\end{array}$ & $\begin{array}{c}\text { Teško } \\
\text { mucanje }\end{array}$ & $\begin{array}{c}\text { Nema } \\
\text { mucanja }\end{array}$ \\
\hline
\end{tabular}

SSI-4, osim stupnja jakosti mucanja, procjenjuje i ispitanikove osjećaje povezane $\mathrm{s}$ mucanjem, ovisno o situacijama i vrsti slušatelja (prijatelj, roditelj, stranac, autoritet, telefonski razgovor). Prema rezultatima (Tablica 3), svim ispitanicima najlakše je razgovarati s roditeljima. Nakon toga, redom, idu telefonski razgovori i bliski prijatelji, dok im je najteže razgovarati s autoritetima. Prvi

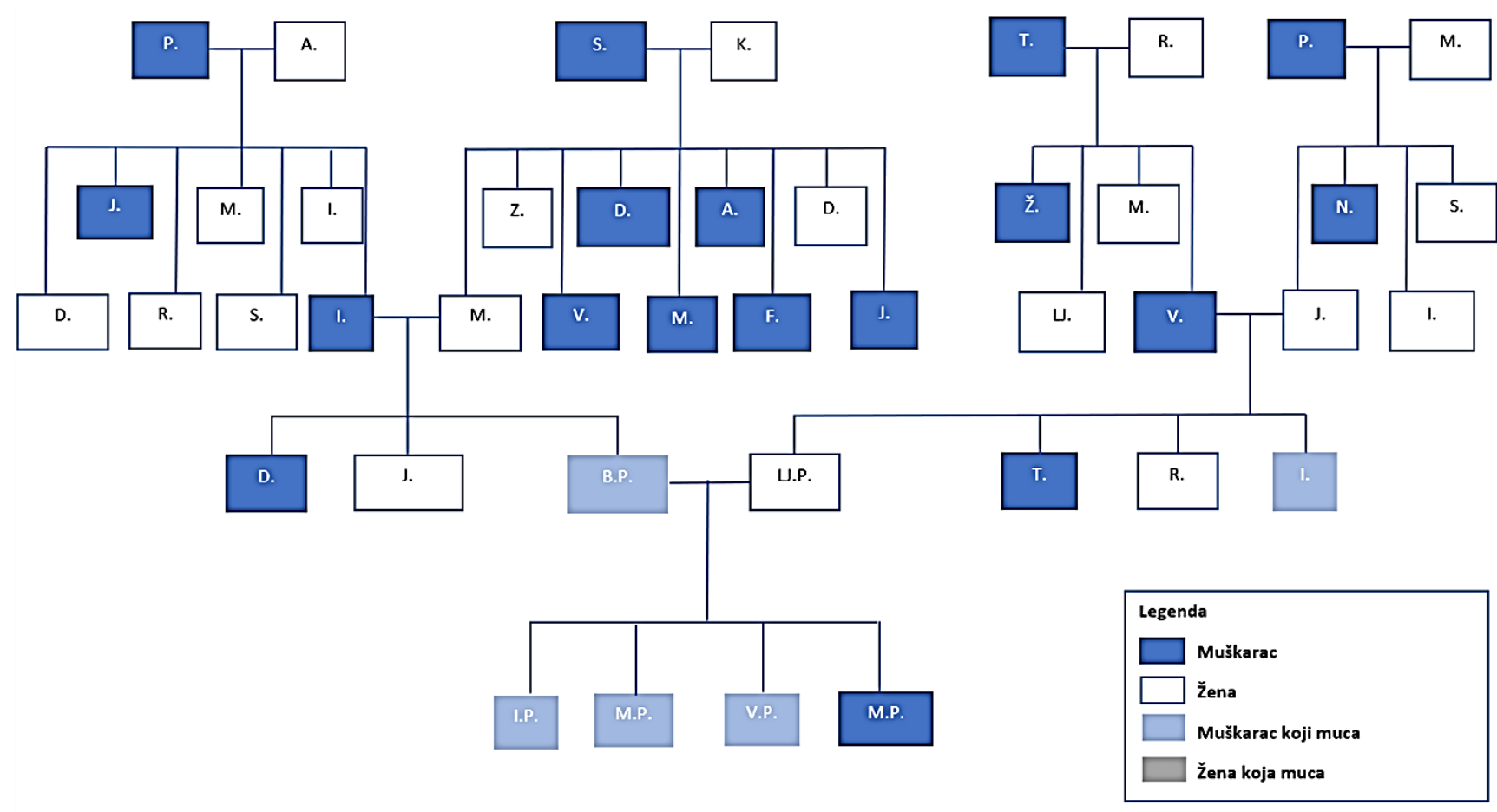

Slika 1. Obiteljsko stablo 
ispitanik pokazuje najpozitivnije osjećaje vezane uz mucanje. Pretpostavlja se da je rezultat u skladu s njegovim stupnjem mucanja (vrlo blago mucanje). Zanimljivo je naglasiti da mu je jednaka težina telefonskih razgovora $i$ razgovora $s$ roditeljima. Navedeno se može povezati s njegovim radnim mjestom u pozivnom centru, gdje je svakodnevno obavljao telefonske razgovore. Drugi ispitanik pokazuje negativnije osjećaje vezane uz mucanje od trećeg ispitanika, iako treći ispitanik ima teži stupanj mucanja. Zaključak je da stvarna slika o vlastitom mucanju ne mora biti vezana i uz njegovu jakost, pogotovo kad je mucanje uočljivo i prepoznatljivo.

Tablica 2. Rezultati primjene PPVT-testa

\begin{tabular}{|c|c|c|c|c|}
\hline & $\begin{array}{c}\text { Prvi } \\
\text { ispitanik }\end{array}$ & $\begin{array}{c}\text { Drugi } \\
\text { ispitanik }\end{array}$ & $\begin{array}{c}\text { Treći } \\
\text { ispitanik }\end{array}$ & $\begin{array}{c}\text { Četvrti } \\
\text { ispitanik }\end{array}$ \\
\hline SR & 187 & 173 & 143 & 71 \\
\hline $\mathbf{Z}$ & 105 & 92 & 74 & 80 \\
\hline $\mathbf{C}$ & 63 & 30 & 4 & 9 \\
\hline KD & 23 & $20 ; 06$ & $16 ; 10$ & 7 \\
\hline DE & $23+$ & $16 ; 02$ & $11 ; 03$ & $6 ; 02$ \\
\hline RB & $\begin{array}{c}\text { Visok } \\
\text { prosjek }\end{array}$ & $\begin{array}{c}\text { Nizak } \\
\text { prosjek }\end{array}$ & $\begin{array}{c}\text { Umjereno } \\
\text { nizak } \\
\text { rezultat }\end{array}$ & $\begin{array}{c}\text { Umjereno } \\
\text { nizak } \\
\text { rezultat }\end{array}$ \\
\hline
\end{tabular}

Legenda: $\mathrm{SR}=$ sirovi rezultat; $\mathrm{Z}=$ standardizirana vrijednost; $\mathrm{C}=$ centil; $\mathrm{KD}=$ kronološka dob; $\mathrm{DE}=$ dobni ekvivalent; $\mathrm{RB}=$ raspon bodova

Tablica 3. Usporedba aritmetičkih sredina odgovora

\begin{tabular}{|l|c|c|c|c|}
\hline & $\begin{array}{c}\text { Prvi } \\
\text { ispitanik }\end{array}$ & $\begin{array}{c}\text { Drugi } \\
\text { ispitanik }\end{array}$ & $\begin{array}{c}\text { Treći } \\
\text { ispitanik }\end{array}$ & $\begin{array}{c}\text { Svi } \\
\text { ispitanici }\end{array}$ \\
\hline Prijatelj & 2 & 5,31 & 4,39 & 3,9 \\
\hline Roditelj & 1,85 & 4,85 & 4,31 & 3,67 \\
\hline Stranac & 2,38 & 4,69 & 6 & 4,36 \\
\hline Autoritet & 2,46 & 6,31 & 5,15 & 4,64 \\
\hline Telefon & 1,85 & 5,77 & 3,92 & 3,85 \\
\hline $\begin{array}{l}\text { Sve } \\
\text { zajedno }\end{array}$ & 2,11 & 5,39 & 4,75 & 4,08 \\
\hline
\end{tabular}

U Tablici 4 prikazane su vrste i postotak netečnosti u snimljenim i transkribiranim govornim iskazima ispitanika. Korištena je kategorizacija autorice Galić-Jušić (2001), prema kojoj su temeljni govorni simptomi mucanja ponavljanja glasova, slogova i riječi, produljivanja, umetanja te zastoji. Prema kvalitativnoj analizi govora, prvi ispitanik najčešće ponavlja slogove i riječi, dok produljivanja, umetanja i zastoja nema u njegovom govoru. Kod ostala dva ispitanika prisutne su sve navedene vrste netečnosti. Drugi i treći ispitanik imaju najviše zastoja, a najmanje produljivanja.

Utjecaj sintaktičke složenosti na frekvenciju mucanja u ovom istraživanju nije se pokazao bitnim. Zapravo, frekvencija mucanja ispitanika veća je na jednostavnim rečenicama nego na složenim (Tablica 5). Ovaj rezultat kosi se s rezultatom koji je dobio Wells (1979) i koji navodi da frekvencija mucanja raste na složenijim rečenicama. Prema očekivanjima - što je veći stupanj jakosti mucanja, veća je i frekvencija netečnosti. Usporedimo li skupine rečenica, možemo primijetiti da se rezultati ispitanika s obzirom na dvije skupine složenih rečenica razlikuju. Drugi i treći ispitanik pokazuju najveću frekvenciju mucanja na složenim rečenicama s ometajućim čimbenikom, dok u običnim složenim rečenicama pokazuju manje mucanja nego u jednostavnim rečenicama. Prvi ispitanik pokazuje manje mucanja što je rečenica sintaktički složenija. No, razlike među jednostavnim i složenim rečenicama kod ispitanika ovog istraživanja nisu toliko izražene i može se reći da su zanemarive.

Tablica 4. Kvalitativna analiza govora

\begin{tabular}{|l|c|c|c|c|}
\hline & $\begin{array}{c}\text { Prvi } \\
\text { ispitanik }\end{array}$ & $\begin{array}{c}\text { Drugi } \\
\text { ispitanik }\end{array}$ & $\begin{array}{c}\text { Treći } \\
\text { ispitanik }\end{array}$ & $\begin{array}{c}\text { Četvrti } \\
\text { ispitanik }\end{array}$ \\
\hline $\begin{array}{l}\text { Ponavljanja } \\
\text { glasova }\end{array}$ & $11,12 \%$ & 21,55 & $8,88 \%$ & $13,85 \%$ \\
\hline $\begin{array}{l}\text { Ponavljanja } \\
\text { slogova }\end{array}$ & $44,44 \%$ & 17,24 & $6,52 \%$ & $22,73 \%$ \\
\hline $\begin{array}{l}\text { Ponavljanja } \\
\text { riječi }\end{array}$ & $44,44 \%$ & 7,76 & $2,96 \%$ & $18,38 \%$ \\
\hline Produljivanja & $0 \%$ & 5,17 & $6,51 \%$ & $3,89 \%$ \\
\hline Umetanja & $0 \%$ & 21,55 & $1,78 \%$ & $7,78 \%$ \\
\hline Zastoji & $0 \%$ & 26,73 & $73,95 \%$ & $33,55 \%$ \\
\hline
\end{tabular}

Tablica 5. Frekvencija mucanja s obzirom na sintaktičku složenost rečenica

\begin{tabular}{|l|c|c|c|}
\hline & $\begin{array}{c}\text { Prvi } \\
\text { ispitanik }\end{array}$ & $\begin{array}{c}\text { Drugi } \\
\text { ispitanik }\end{array}$ & $\begin{array}{c}\text { Treći } \\
\text { ispitanik }\end{array}$ \\
\hline $\begin{array}{l}\text { Jednostavne } \\
\text { rečenice }\end{array}$ & $2,04 \%$ & $9,18 \%$ & $19,39 \%$ \\
\hline Složene rečenice & $1,81 \%$ & $7,69 \%$ & $17,65 \%$ \\
\hline $\begin{array}{l}\text { Složene rečenice s } \\
\text { ometajućim } \\
\text { čimbenikom }\end{array}$ & $1,20 \%$ & $9,52 \%$ & $20,13 \%$ \\
\hline $\begin{array}{l}\text { Obje vrste složenih } \\
\text { rečenica zajedno }\end{array}$ & $1,51 \%$ & $8,61 \%$ & $18,89 \%$ \\
\hline
\end{tabular}

Tablica 6. Usporedba frekvencije mucanja na jednostavnim rečenicama bez/s leksičkim prizivom

\begin{tabular}{|l|c|c|c|}
\hline & $\begin{array}{c}\text { Prvi } \\
\text { ispitanik }\end{array}$ & $\begin{array}{c}\text { Drugi } \\
\text { ispitanik }\end{array}$ & $\begin{array}{c}\text { Treći } \\
\text { ispitanik }\end{array}$ \\
\hline $\begin{array}{l}\text { Jednostavne } \\
\text { rečenice }\end{array}$ & $2,04 \%$ & $9,18 \%$ & $19,39 \%$ \\
\hline $\begin{array}{l}\text { Jednostavne } \\
\text { rečenice s } \\
\text { leksičkim prizivom }\end{array}$ & $1,27 \%$ & $7,41 \%$ & $23,46 \%$ \\
\hline
\end{tabular}

Tablica 7. Usporedba frekvencije mucanja na jednostavnim rečenicama s leksičkim prizivom s rezultatima na Peabody slikovnom testu rječnika (PPVT-III-HR)

\begin{tabular}{|l|c|c|c|}
\hline & $\begin{array}{c}\text { Prvi } \\
\text { ispitanik }\end{array}$ & $\begin{array}{c}\text { Drugi } \\
\text { ispitanik }\end{array}$ & $\begin{array}{c}\text { Treći } \\
\text { ispitanik }\end{array}$ \\
\hline $\begin{array}{l}\text { Jednostavne } \\
\text { rečenice s } \\
\text { leksičkim prizivom }\end{array}$ & $1,27 \%$ & $7,41 \%$ & $23,46 \%$ \\
\hline PPVT-III-HR & $\begin{array}{c}\text { Visok } \\
\text { prosjek }\end{array}$ & $\begin{array}{c}\text { Nizak } \\
\text { prosjek }\end{array}$ & $\begin{array}{c}\text { Umjereno } \\
\text { nizak } \\
\text { rezultat }\end{array}$ \\
\hline
\end{tabular}


Prema većini istraživanja (primjerice, Pellowski i Conture, 2005), osobe koje mucaju sporije pronalaze riječi u svom mentalnom leksikonu. Leksički priziv ispitanika ovog istraživanja sam po sebi nije se pokazao utjecajnim kod svih ispitanika na frekvenciju mucanja (Tablica 6). Štoviše, prva dva ispitanika koji mucaju pokazuju veći stupanj mucanja na jednostavnim rečenicama bez leksičkog priziva, dok treći ispitanik pokazuje više netečnosti na jednostavnim rečenicama s leksičkim prizivom. Međutim, u Tablici 7 vidljivo je da se ovaj rezultat u potpunosti slaže s rezultatom na mjeri receptivnog rječnika ispitanika. Što je viša razina receptivnog rječnika, to je niža frekvencija mucanja na rečenicama koje zahtijevaju dodatnu jezičnu obradu odnosno leksički priziv. Zabilježena jezična slabost trećeg ispitanika implicira da postoje teškoće pronalaženja riječi u njegovom mentalnom leksikonu, te se tako učestale netečnosti možebitno javljaju kao posljedica toga.

Ograničenja ovog istraživanja su u malom uzorku ispitanika, što povlači problem generalizacije njegovih rezultata. Kako bi rezultati bili reprezentativniji, bilo bi učinkovitije ispitati više generacija iste obitelji ili usporediti više različitih obitelji.

\section{ZAKLJUČAK}

Ovim istraživanjem obuhvaćena je jedna generacija obitelji genetski opterećene mucanjem. Utvrđena je razina njihovih jezičnih sposobnosti, kvantitativna i kvalitativna analiza netečnosti, njihovi osjećaji povezani s mucanjem te utjecaj zahtjeva jezične obrade (sintaktičke složenosti i leksičkog priziva) na pojavu netečnosti.

Prema obiteljskom stablu, $75 \%$ članova iste generacije ima prisutno mucanje uz još dva člana obitelji izvan spomenute generacije (otac i ujak). Stupanj jakosti mucanja razlikuje se ovisno o ispitaniku. Prvi ispitanik pokazuje vrlo blago mucanje, drugi umjereno mucanje, treći teško mucanje, a četvrti uopće ne pokazuje mucanje. Rezultati pokazuju da su jezične sposobnosti jedne polovice generacije unutar prosjeka, a kod druge polovice su ispodprosječne. Potvrđeno je da sintaktička složenost nema utjecaja na jakost mucanja, odnosno povećanjem sintaktičke složenosti mucanje nije češće. Nadalje, leksički priziv ima utjecaja na pojavu netečnosti, ali samo kod ispitanika kod kojeg su zabilježene ispodprosječne jezične sposobnosti. Kod ostalih ispitanika takvi zahtjevi jezične obrade ne utječu na frekvenciju mucanja. Vezano uz osjećaje povezane s mucanjem, ispitanicima je općenito najlakše voditi razgovor $s$ roditeljima, zatim telefonski razgovor, razgovor s bliskim prijateljem te strancem, a najteže im je razgovarati $s$ autoritetima. Kvantitativnom analizom govora utvrđeno je da se od svih vrsta netečnosti najviše javljaju zastoji, a najmanje produljivanja. Kad se uzme u obzir cijela generacija obitelji, dobiveni rezultati ne dokazuju povezanost mucanja i jezika. No, analizom rezultata svakog ispitanika i utvrđivanjem njihovih velikih međusobnih razlika, može se potvrditi kako je mucanje heterogen poremećaj. Prema tome, $\mathrm{u}$ nekim slučajevima nedostaci jezične obrade zajedno $\mathrm{s}$ genetskom predispozicijom za mucanje mogu doista dovesti do pojave i razvoja mucanja, kao što je slučaj trećeg ispitanika. No, kod ostalih ispitanika isključen je čimbenik narušenih jezičnih sposobnosti i mucanje je također nastupilo, iako u nižim stupnjevima jakosti. Stoga se može reći da je genetsko naslijeđe zapravo vrlo jak čimbenik za nastanak mucanja. Međutim, ne mogu se isključiti i ostali rizični čimbenici - poput zrelosti, količine terapije, okoline i slično. Četvrti ispitanik je potvrda da se mucanje ne mora nužno razviti, unatoč prisutnosti više rizičnih čimbenika. Zaključno, spoznaja da su mucanje i jezik donekle povezani vrlo je važno kliničarima, koji se u dijagnostici i terapiji trebaju osvrnuti ne samo na tečnost govora nego i na jezične sposobnosti osoba koje mucaju.

\section{LITERATURA}

1) Abel, A. D., Maguire, M. J., Naqvi, F. M. \& Kim, A. Y. (2014). Lexical retrieval of nouns and verbs in a sentence completion task. Journal of Psycholinguistic Research, 44 (5), 545 53. DOI: $10.1007 / \mathrm{s} 10936-014-9304-8$

2) Anderson, J. D. \& Conture, E. G. (2000). Language abilities of children who stutter: A preliminary study. Journal of Fluency Disorders, 25, 283-304. DOI: 10.1016/S0094730X(00)00089-9

3) Barnes MacFarlane, W., Hanson, M., Walton, W. \& Mellon, C. D. (1991). Stuttering in five generations of a single family. A preliminary report including evidence supporting a sex-modified mode of transmission. Journal of Fluency Disorders, 16, 117-23. DOI: 10.1016/0094730X(91)90016-6

4) Blood, G. W., Blood, I. M., Tellis, G. M. \& Gabel, R. M. (2003). A preliminary of study self-esteem, stigma and disclosure in adolescents who stutter. Journal of Fluency Disorders, 28, 143-59. DOI: 10.1016/S0094-730X(03)00010$\mathrm{X}$

5) Bloodstein, O. \& Bernstein Ratner, N. (2008). A handbook on stuttering. New York: Delmar.

6) Craig, A. \& Tran, Y. (2005). The epidemiology of stuttering: The need for reliable estimates of prevalence and anxiety levels over the lifespan. Advances in Speech Language Pathology, 7, 41-6. DOI: 10.1080/14417040500055060

7) Dunn, L. M., Dunn, L. M., Kovačević, M., Padovan, N., Hržica, G., Kuvač Kraljević, J., Mustapić, M., Dobravac, G. i Palmović, M. (2009). Priručnik za PPVT-III-HR. Jastrebarsko: Naklada Slap.

8) Choi, D., Conture, E. G., Tumanova,V., Clark, C. E., Walden, T. A. \& Jones, R. M. (2018). Young children's family history of stuttering and their articulation, language and attentional abilities. An exploratory study. Journal of Communication Disorders, 71, 22-36. DOI: 10.1016/j.jcomdis.2017.11.002

9) Crocker, J. \& Major, B. (1989). Social stigma and selfesteem: The self-protective properties of stigma. Psychological review, 96(4), 608.

10) Dunn, L. M. \& Dunn, L. M. (1997). PPVT-III: Peabody picture vocabulary test. American Guidance Service.

11) Galić-Jušić, I. (2001). Što učiniti s mucanjem: Cjelovit pristup govoru i psibi. Lekenik: Ostvarenje.

12) Gray, M. (1940). The X Family: A Clinical and Laboratory Study of a "Stuttering" Family. Journal of Speech Disorders, 5, 343-48. DOI: 10.1044/jshd.0504.343

13) Kleinow, J. \& Smith, A. (2000). Influences of lenght and syntactic complexity on the speech motor stability of the fluent speech of adults who stutter. Journal of Speech, Language 
and Hearing Research, 43, 548-59. DOI:

10.1044/jslhr.4302.548

14) MacPherson, M. K. \& Smith, A. (2013). Influences of sentence length and syntactic complexity on the speech motor control of children who stutter. Journal of Speech, Language, and Hearing Research, 56, 89-102. DOI: 10.1044/1092-4388(2012/11-0184)

15) Ntourou, K., Conture, E. \& Lipsey, M. W. (2011). Language abilities of children who stutter: A metaanalytical review. American Journal of Speech-Language Pathology, 20,163-79. DOI: 10.1044/1058-0360(2011/09-0102)

16) Ooki, S. (2005). Genetic and environmental influences on stuttering and tics in Japanese twin children. Twin Research and Human Genetics, 8, 69-75. DOI: 10.1375/twin.8.1.69

17) Pellowski, M. W. (2011). Word-finding and vocabulary abilities of adults who do and do not stutter. Contemporary Issues in Communication Science and Disorders, 38, 126-34.

18) Pellowski, M. W. \& Conture, E. G. (2005). Lexical priming in picture naming of young children who do and do not stutter. Journal of Speech, Language and Hearing Research, 48, 278-94. DOI: 10.1044/1092-4388(2005/019)

19) Perkins, W. H., Kent, R. D. \& Curlee, R. F. (1991). A theory of neuropsycholinguistic function in stuttering. Journal of Speech, Language, and Hearing Research, 34(4), 734-52. DOI: $10.1044 /$ jshr.3404.734

20) Riley, G. (2009). SSI-4: Stuttering severity instrument $\left(4^{\text {th }}\right.$ ed.). Austin: Pro-Ed.

21) Salihović, N., Januzović-Žunić, L., Duranović, M. \& Fatusić, A. (2010). Characteristic of vocabulary in school-age stuttering children. The Journal of International Social Research, 3, 399-406.

22) Schuell, H. (1946). Sex Differences in Relation to Stuttering: Part I. Journal of Speech Disorders, 11, 277-98. DOI: 10.1044/jshd.1104.277

23) Silverman, S. W. \& Bernstein Ratner, N. (1997). Syntactic complexity, fluency, and accuracy of sentence imitation in adolescents. Journal of Speech, Language and Hearing Research, 40, 95-106. DOI: 10.1044/jslhr.4001.95

24) Starkweather, C. W. \& Gottwald, S. R. (1990). The demands and capacities model II: Clinical application. Journal of Fluency Disorders, 15, 143-57. DOI: 10.1016/0094730X(90)90015-K

25) Usler, E., Smith, A. \& Weber, C. (2017). A lag in speech motor coordination during sentence production is associated with stuttering persistence in young children. Journal of Speech, Language, and Hearing Research, 60, 51-61. DOI: 10.1044/2016_JSLHR-S-15-0367

26) van Beijsterveldt, C. E. M., Felsendeld, S. \& Boomsma, D. I. (2010). Bivariate genetic analysis of stuttering and nonfluency in a large sample of 5-year-old-twins. Journal of Speech, Language and Hearing Research, 53, 609-19. DOI: 10.1044/1092-4388(2009/08-0202)

27) Yairi, E., Ambrose, N. \& Cox, N. (1996). Genetics of stuttering. Journal of Speech, Language, and Hearing Research, 39, 771-84. DOI: 10.1044/jshr.3904.771

28) Yairy, E. \& Seery, C. H. (2015). Stuttering: Foundations and clinical applications. Harlow: Pearson Education.

29) Wells, G. B. (1979). Effect of sentence structure on stuttering. Journal of Fluency Disorders, 4, 123-29. DOI: 10.1016/0094-730X(79)90011-1 